\title{
Mechanisms of viral pathogenesis in rheumatic disease
}

Considerable evidence indicates that viruses may be important environmental factors in the pathogenesis of autoimmune rheumatic diseases. A concordance rate of $25 \%$ for the most common illnesses, such as rheumatoid arthritis (RA) or systemic lupus erythematosus (SLE) in monozygotic twins shows that genetic factors influence susceptibility to autoimmune diseases. ${ }^{1}$ Alternatively, a $70 \%$ discordance rate emphasises the importance of environmental factors. Forensic studies of archeological sites revealed the presence of RA-like erosive bony changes in pre-Columbian New World populations dating back 6500 years and the absence of RA in the Old World before the 18 th century. ${ }^{2}$ This geographical distribution suggests that RA may have spread from the Americas through environmental factors, possibly by a virus, another microorganism, or an antigen. Viruses can elicit acute or subacute and, less often, chronic forms of arthritis. These viral arthritis syndromes can be diagnosed by recognition of well defined clinical signs and detection of viral antibodies and nucleic acids. Viral elements may also play a part in the pathogenesis of idiopathic autoimmune rheumatic diseases. This editorial will assess mechanisms of viral pathogenesis in rheumatic disease by focusing on known viruses capable of causing inflammatory arthritis syndromes and comparing virally induced immunological aberrations with those noted in rheumatic disease patients.

\section{Well defined virus induced rheumatic diseases}

Viral infections often lead to inflammatory syndromes where arthralgias or arthritis may represent a major manifestation. Most cases of viral arthritis, such as rubella or parvovirus B19 arthropathies are short-term and self limited as a result of an efficient elimination of the organism by the immune system. Chronic arthropathies have been associated with persistent or latent viral infections, virus induced autoimmunity, polyclonal B cell activation, and immunodeficiency resulting in opportunistic infections, largely because of an inability of the immune system to eliminate the pathogen. This latter group of viruses include human immunodeficiency virus 1 (HIV-1), human T-cell lymphotropic virus type I (HTLV-I), and hepatitis C virus $(\mathrm{HCV})$.

\section{VIRUS INDUCED TRANSIENT ARTHRITIS SYNDROMES} Parvovirus B19

Parvovirus B19 is one of the most frequent causes of viral arthritis. $^{3}$ Joint manifestations are temporally associated with production of anti-B19 IgM antibodies. While involvement of B19 has been repeatedly raised in classic RA, large surveys failed to demonstrate an association between erosive RA and parvovirus B19. ${ }^{3}$

\section{Rubella virus}

Rubella is known to cause mild and self limited arthralgias and acute arthritis. ${ }^{4}$ Chronic arthropathy was reported in $1-4 \%$ of postpartum female recipients of the RA27/3 vaccine strain. ${ }^{5}$ Other studies found no increase of chronic arthritis in women receiving the RA27/3 rubella vaccine. ${ }^{6}$ Moreover, no rubella virus can be recovered from periph- eral blood lymphocytes of persons with chronic arthropathy following rubella infection or vaccination. ${ }^{7}$ Therefore, continued vaccination of rubella susceptible women to reduce the risk of congenital malformations seems warranted.

\section{Alphaviruses}

These are arthropod borne viruses that include the chikungunya, o'nyong-nyong, Mayaro, Sindbis, Okelbo, Barmah Forest (BF) and Ross River (RR) viruses. Similar to the rubella virus, they belong to the Togavirus family containing a positive strand RNA genome. The viruses are spread by mosquitos in endemic areas of Australia (Sindbis, BF, and RR), South America (Mayaro), northern Europe (Okelbo), Asia and sub-Saharan Africa (chikungunya). They can cause an acute infectious illness with rash, fever, arthritis, myalgia and/or encephalitis. RR virus is the aetiological agent of the best studied epidemic polyarthrtitis (EPA) affecting up to 7800 Australians annually. ${ }^{8}$ Persistent infections are believed to be responsible for chronic arthritidis. CD4+ T cells dominate mononuclear synovial effusions of EPA patients in contrast with $\mathrm{CD} 8+\mathrm{T}$ cell infiltrate in rashes of $\mathrm{RR}$ virus infected patients who made early and complete recoveries. ${ }^{9}{ }^{10} \mathrm{EPA}$ involves the small joint of the hand and often causes tendonitis. Symptoms may persist for months. No erosive changes have been reported. The diagnosis is made by demonstrating $\operatorname{IgM}$ antibodies to RR virus. ${ }^{11}$

\section{Adenoviruses}

These viruses are a common cause of acute respiratory infections. Symmetric polyarthritis of small and large joints may occur within a week of respiratory symptoms. ${ }^{12}$ Recurrent chronic oligoarthritis because of adenovirus infection was rarely reported..$^{13}$

\section{Coxsackieviruses}

They belong to the group of enteroviruses. More than $90 \%$ of coxsackievirus infections are asymtomatic or manifest in undifferentiated febrile illness. Spectrum and severity of disease manifestations vary with age, sex, and immune status of the host. ${ }^{15}$ Coxsackievirus arthritis, usually caused by Group B virus, occurs with fever, serositis, pleurodynia, and rash. The arthritis is usually symmetric and polyarticular, involving both small and large joints.

\section{Herpesviruses}

After initial infection, viruses of the Herpesviridae family persist in the host with lifelong latency. Therefore, several of these viruses have been considered as aetiological agents in autoimmune diseases, such as systemic lupus erythematosus (SLE), RA, or Sjögren's syndrome (see below). Epstein-Barr virus (EBV) infection causes arthralgias lasting for up to four months in $2 \%$ of patients with mononucleosis. ${ }^{16}$ Recently, EBV positive lymphomas were described in methotrexate treated RA patients. ${ }^{17}{ }^{18}$ Interestingly, remission of lymphomas was noted after discontinuation of methotrexate. ${ }^{17} \mathrm{HSV}-1$ arthritis rarely lasts longer 
than two weeks. Varicella-zoster virus (VZV) can cause monarthritis, mostly in the knee, as a rare complication of chickenpox. ${ }^{19}$ Cytomegalovirus (CMV) may be responsible for scleroderma-like changes in patients with chronic graft versus host disease. ${ }^{20}$ These patients carry CD13 autoantibodies that bind to skin and mucous membranes. CMV incorporates the human CD13 protein into their viral envelope that may be responsible for generation of autoantibodies.

\section{Hepatitis $B$ virus ( $H B V)$}

HBV can cause arthralgias and arthritis early after infection. Arthritis resolves in 2-6 weeks with the onset of jaundice. Hepatitis B virus has been also associated with polyarteriitis nodosa and cryoglobulinaemia.

\section{VIRUS INDUCED CHRONIC RHEUMATIC DISEASES}

Hepatitis $C$ virus (HCV)

$\mathrm{HCV}$ has a wide pathogenic potential that is not limited to diseases of the liver. ${ }^{21}$ Despite high titre antibody concentrations, $>80 \%$ of infected people become chronic virus carriers. Cryoglobulinaemia is detectable in up to $40-50 \%$ of HCV infected patients. ${ }^{22}$ Identification of $\mathrm{HCV}$ as the causal agent of most (>90\%) type II or essential mixed cryglobulinaemias (EMC) has been a major breakthrough of rheumatology in the past decade. ${ }^{23}$ Type II cryoglobulins are immune complexes comprised of a monoclonal $\operatorname{IgM} / \kappa$ rheumatoid factor and polyclonal IgG. The clinical syndrome of EMC is an immune complex vasculitis characterised by purpura, arthralgias, inflammatory arthritis, peripheral neuropathy, and glomerulonephritis. ${ }^{24}$ $\operatorname{IgM} / \kappa$ bearing $\mathrm{B}$ cells are clonally expanded in the peripheral blood of EMC patients. ${ }^{25}$ Infection by HCV may be directly responsible for the clonal expansion of $\mathrm{B}$ cells, ${ }^{26}$ which may lead to development of B-cell non-Hodgkin's lymphomas. ${ }^{21} \mathrm{HCV}$ infection is associated with production of autoantibodies. Up to $75 \%$ of the patients have high titre rheumatoid factors, presumably produced by $\mathrm{HCV}$ infected and clonally expanded B lymphocytes. Fifty per cent or more of the patients have anti-smooth muscle antibodies. Low titre antinuclear antibodies and anticardiolipin antibodies were noted in $10-30 \%$ of $\mathrm{HCV}$ infected patients. Five per cent of patients may develop Sjögren's syndrome, SLE, autoimmune thyroiditis, or scleroderma. ${ }^{27}$ Erosive/rheumatoid arthritis, and polymyositis/dermatomyositis were rarely documented. ${ }^{21}$

\section{Human T cell lymphotropic virus I (HTLV-I)}

Infection by HTLV-I has been associated with adult $\mathrm{T}$ cell leukaemia (ATL), mycosis fungoides/Sézary syndrome, HTLV-I associated myelopathy/tropic spastic paraparesis (HAM/TSP), HTLV-I associated arthritis (HAA), polymyositis, and Sjögren's syndrome. ${ }^{28}$ Despite very high rates of infection in endemic areas where $30 \%$ or more of the population may be infected, relatively few $(<1 \%)$ infected people show disease manifestations attributable to HTLV-I. The lifetime risk of developing a HTLV-I associated disorder is less than 5\%. Polymyositis, Sjögren's syndrome, and inflammatory arthritis may occur in the absence of leukaemia. They are characterised by infiltration of the skeletal muscle, salivary glands, or synovium with HTLV-I infected T lymphocytes. HAA is characterised by erosive symmetrical polyarthritis most often involving the hands. The patients may have rheumatoid factor or antinuclear antibodies and usually satisfy the diagnostic criteria for RA. ${ }^{29}$ Arthroscopic studies revealed proliferative synovitis in HAA. ${ }^{28} \mathrm{~T}$ cells infiltrating the joint have indented cerebriform nuclei similar to those seen in ATL. Prevalence of RA is increased in the HTLV-I infected population $(0.56 \%)$ with respect to the uninfected population of Japan $(0.31 \%){ }^{28}$ Thus, the relatively low disease frequency in virus infected people strongly advocates for the role of factors other than HTLV-I in the development of RA. Transgenic mice carrying the tax transactivator gene of HTLV-I develop Sjögren's syndrome and rheumatoid-like arthritis, indicating a pathogenic role for the p40/tax protein. ${ }^{28}$ HTLV-I was also shown to induce polymyositis, arthritis, and uveitis in rhesus macaque monkeys, ${ }^{30}$ thus establishing a primate model of viral arthritis.

Human immunodeficiency virus 1 (HIV-1)

During the course of HIV-1 infection three major phases can be distinguished. Within a few weeks after infection, extensive viraemia occurs giving rise to an acute mononucleosis-like syndrome. A second and relatively latent period represents an ongoing fierce battle between virus replication and replenishing of the CD4 T cell reservoirs. On average, 10 years after infection, diminished CD4 $\mathrm{T}$ cell function gives rise to opportunistic infections, lymphomagenesis, and autoimmune phenomena at the final stages of disease. Polyclonal B cell activation and production of autoantibodies have been attributed to a shift from Th1 type to Th2 type helper $\mathrm{T}$ cell predominance (see below). Rheumatic diseases most commonly noted in patients with AIDS include Reiter's syndrome, psoriatic arthritis, spondylarthropathies, and diffuse infiltrative lymphocytosis syndrome (DILS). Interestingly, all of these syndromes have been associated with relative expansion of CD8 $\mathrm{T}$ cells, thus suggesting that $\mathrm{HIV}-1$ infection accelerates HLA class I restricted CD8 $\mathrm{T}$ cell mediated autoreactivity. ${ }^{31}$ In turn, SLE, RA, and polymyositis, which are thought to be mediated by CD $4 \mathrm{~T}$ cells, remit in some patients after infection by HIV $-1 .^{32}$

\section{Caprine arthritis-encephalitis virus (CAEV)}

Like HIV-1, CAEV belongs to the lentivirus subfamily of the Retroviridae. These viruses cause multiorgan diseases that are apparent only months or years after infection. Visna virus, the prototype non-primate lentivirus, causes pneumonitis and progressive demyelinating neurological disease in the sheep. ${ }^{33} \mathrm{CAEV}$, which is closely related to visna virus, causes neurological diseases in young animals and chronic arthritis and mastitis in adult goats. ${ }^{34} 35$ Primary host cells of CAEV are monocytes and macrophages. Up to $40 \%$ of infected goats develop chronic arthritis characterised by infiltration of the synovium by macrophages, B lymphocytes, plasma cells, CD4+ and CD8+ T cells. CAEV induced arthritis leads to erosions of articular surfaces. CD4+ T cells infiltrating the arthritis joints are predominantly of $\mathrm{T}$ helper type $2 .{ }^{36}$ Similar to $\mathrm{RA}$, tumour necrosis factor $\alpha(\mathrm{TNF} \alpha)$ concentrations are increased in synovial fluid of CAEV infected arthritis goats. ${ }^{37}$ Many naturally or experimentally infected goats are long term non-progressor, characterised by relatively low virus loads and a dominance of viral envelope protein specific Th1 type CD4+ $\mathrm{T}$ helper cells in the peripheral blood. ${ }^{36}$ (Table 1).

\section{Viral pathogenesis in idiopathic autoimmune diseases}

Independent lines of evidence suggest a viral aetiology in autoimmune rheumatic diseases. The possibility of a viral aetiology was raised by findings of virion-like tubuloreticular structures in endothelial cells and lymphocytes as well as demonstration of increased serum concentrations of type I 
Table 1 Virus induced rheumatic diseases

\begin{tabular}{|c|c|c|c|c|c|c|}
\hline Virus & Arthritis frequency & Arthritis type & Duration & Erosion & Other & Reference \\
\hline Parvovirus B19 & $\begin{array}{l}\text { Children: } 5-10 \% \\
\text { Adults: } 50-70 \% \\
\text { Female:male }=2: 1\end{array}$ & $\begin{array}{l}\text { Polyarticular, small and large } \\
\text { joints, symmetrical }\end{array}$ & $\begin{array}{l}2-8 \text { weeks, rarely } \\
\text { chronic }\end{array}$ & No & $\begin{array}{l}\text { Anaemia } \\
\text { Leucopenia } \\
\text { Thrombopenia } \\
\text { Vasculitis } \\
\text { Autoantibodies }\end{array}$ & (3) (90) \\
\hline Rubella & $10-30 \%$ & $\begin{array}{l}\text { Multiple small joints } \\
\text { Autoantibodies }\end{array}$ & 5-10 days & No & $\begin{array}{l}\text { Vaccine strain } \\
\text { RA27/3 may induce arthritis }\end{array}$ & $(4,43)$ \\
\hline VZV & $<1 \%$ & Monoarthritis & $1-7$ days & No & Life long latency & (19) \\
\hline EBV & $1-5 \%$ & Poly or monoarthritis & $1-12$ weeks & No & Autoantibodies & (16) \\
\hline $\mathrm{HBV}$ & $10-25 \%$ & Symmetrical, migratory & $1-3$ weeks & No & Vasculitis & (43) \\
\hline $\mathrm{HCV}$ & $10-50 \%$ & Polyarticular, symmetrical & Chronic & No & $\begin{array}{l}\text { Vasculitis } \\
\text { Sjögren's } \\
\text { Autoantibodies }\end{array}$ & (23) \\
\hline HTLV-I & $<1 \%$ & Oligoarthritis, large joints & Chronic & Yes & $\begin{array}{l}\text { Sjögren's } \\
\text { Polymyosistis } \\
\text { Autoantibodies } \\
\text { CD4 T cell expansion }\end{array}$ & (28) \\
\hline HIV-1 & $10-50 \%$ & $\begin{array}{l}\text { Painful joint syndrome } \\
\text { Reiter's syndrome } \\
\text { Psoriatic arthritis }\end{array}$ & $\begin{array}{l}1-2 \text { days } \\
\text { Chronic } \\
\text { Chronic }\end{array}$ & $\begin{array}{l}\text { No } \\
\text { Yes } \\
\text { Yes }\end{array}$ & $\begin{array}{l}\text { Promotion of CD8 T cell } \\
\text { mediated autoimmunity }\end{array}$ & $(32)$ \\
\hline Alphaviruses & $>50 \%$ & Symmetrical, small joints & 1 week to months & No & fever, myalgia encephalitis & $(11)$ \\
\hline Adenovirus & rare & Small and large joints & transient or chronic & No & Pharyngitis & $(12-14)$ \\
\hline Coxsackie & rare & $\begin{array}{l}\text { Symmetric, small and large } \\
\text { joints }\end{array}$ & acute or chronic & No & $\begin{array}{l}\text { Myocarditis, Serositis, } \\
\text { pleurodynia }\end{array}$ & (15) \\
\hline
\end{tabular}

VZV, varicella-zoster virus; EBV, Epstein-Barr virus = human herpesvirus 4; HBV, hepatitis B virus; HCV, hepatitis C virus; HTLV-I, human T cell lymphotropic virus I; HIV-1, human immunodeficiency virus I.

interferon (IFN) in lupus patients. ${ }^{38}$ Virus-like particles were also noted in RA synovium. ${ }^{39}$ Many viral infections are accompanied by production of autoantibodies and viral proteins have profound effects on both antigen presentation and effector functions of the immune system. Dysregulation of programmed cell death has been reported in HIV infected ${ }^{40}$ and lupus patients as well. ${ }^{41}$ Similar to SLE, anaemia, leucopenia, thrombocytopenia, polymyositis, and vasculitis have been widely reported in patients with AIDS. ${ }^{42}$ Direct virus isolation and transmission attempts from tissues of autoimmune patients have not been successful. ${ }^{43}$ Nevertheless, it is possible that a (retro)virus, responsible for provoking an immune response cross reactive with self antigens, has been cleared from the host, so the absence of viral particles is not conclusive. An alternative retroviral aetiology-that is, activation of endogenous retroviral sequences (ERS) was initially proposed by a study of the New Zealand mouse model of SLE. ${ }^{44}$ Endogenous retroviral envelope glycoprotein, gp 70, was found in immune complex deposits of autoimmune lupus prone NZB/NZW mice. Abnormal expression of an ERS was noted in the thymus of lupus prone mouse strains. ${ }^{45}$ More recently, expression and autoantigenicity of human ERS has been demonstrated in patients with SLE. ${ }^{46-50}$

Below, two possible mechanisms of viral pathogenesis will be discussed. The first scenario involves molecular mimicry causing abnormal self reactivity. ${ }^{51}$ Naturally, viral infections elicit potent antiviral immunity that may lead to cross reactivity against self antigens. Analysis of molecular mimicries that is delineation of autoantigenic epitopes of self antigens may provide clues to the identity of viral antigens responsible for triggering the cross reactive immune responses. Secondly, infection of genetically susceptible hosts by a potentially large number of commonly occurring viruses may lead to $\mathrm{T}$ and $\mathrm{B}$ cell dysfunction and autoimmunity. Immunoregulatory aberrations triggered by well defined viral proteins at the level of antigen presentation, modulation of cytokine activities, and disruption of cell death pathways, will be discussed.

STRUCTURAL MIMICRY AND CROSS REACTIVITY BETWEEN VIRAL PROTEIN AND AUTOANTIGENS

Under normal conditions, the immune system develops a potent virus specific immune response that rapidly eliminates the virus with only minimal tissue injury. Only minimal amounts of self antigens are released, which are insufficient to induce autoreactive $\mathrm{B}$ and $\mathrm{T}$ lymphocytes and autoimmune disease will not ensue. However, in the event that the host and the virus share antigenic determinants, virus infection may result in autoimmunity as virus specific $T$ cells and antibodies are cross reactive with self antigens. This scenario does not preclude the possibility that the infecting virus is eliminated by the immune response. Alternatively, similarities between proteins of the major histocompatibility complex (MHC) and microbial antigens, especially viral antigens, may allow the host to regard an infectious agent as self and, thus, forego an immune response. The "shared epitope" QKRAA sequence from the third hypervariable region of HLA DRB ${ }^{\star} 0401$, which has been found in numerous human pathogens, is associated with susceptibility to RA. ${ }^{52}$ The $70 \mathrm{~K}$ protein of $\mathrm{U} 1 \mathrm{snRNP}$ was the first lupus autoantigen shown to contain a region of homology and immunological cross reactivity with a conserved p30 gag protein of most mammalian type $\mathrm{C}$ retroviruses (table 2). Based on this obsevation, Query and Keene proposed that autoimmunity to U1RNP may be triggered by expression by an endogenous retroviral gag protein..$^{53}$ Anti-gag antibodies elicited by the ERS could cross react with the $70 \mathrm{~K}$ protein and, subsequently, recognition could expand to addtional $70 \mathrm{~K}$ epitopes.

The ERS capable of triggering antibodies cross reactive with the $70 \mathrm{~K}$ protein may correspond to HRES-1, a human T-cell lymphotropic virus related endogenous sequence. ${ }^{4754}$ In different laboratories, prevalance of HRES-1 antibodies may be as high as $52 \%{ }^{47}$ or as low as $21 \%{ }^{49}$ in patients with SLE. Fifty nine per cent (10 of 15$)$

Table 2 Molecular mimicry between viral proteins and autoantigens

\begin{tabular}{lllll}
\hline Autoantigen & $\begin{array}{l}\text { Prevalence } \\
(\%)^{\star}\end{array}$ & $\begin{array}{l}\text { Viral } \\
\text { protein }\end{array}$ & Virus & Reference \\
\hline 70k/U1 snRNP & 30 & gag & MoMLV, HRES-1 & $(47,53)$ \\
HRES-1 & $21-52$ & gagp24 & HTLV-I & $(46-49)$ \\
Sm B/B' & 30 & gagp24 & HIV-1 & $(59)$ \\
C/U1 snRNP & 30 & ICP4 & HHV-1 & $(64)$ \\
Sm D & 36 & EBNA-1 & EBV & $(60)$ \\
Sm B/B' & $25-40$ & EBNA-1 & EBV & $(63)$ \\
La & 15 & gag & FSV & $(65)$ \\
p542 & $10-50$ & EBNA-1 & EBV & $(61)$ \\
ERV-3 & 32 & env & MoMLV & $(50)$ \\
\hline
\end{tabular}

^Prevalence of antibodies in patients with SLE. 
of scleroderma, $44 \%$ (8 of 18 ) of primary SJS, $19 \%$ (3 of 16) of polymyositis/dermatomyositis patients also had HRES-1 antibodies. By contrast 3.6\% (4 of 111) of normal donors and none of 42 patients with AIDS or 50 asymptomatic HIV infected patients had HRES-1 antibodies. ${ }^{47}$ The retroviral gag related region of the $70 \mathrm{~K}$ protein shares three consecutive highly charged amino acids, Arg-Arg-Glu (RRE), an additional Arg and functionally similar Arg/Lys residues with HRES-1/p28 that represent cross reactive epitopes between the two proteins. ${ }^{46}{ }^{45}$ Interestingly, the RRE triplet is repeated three times in the $70 \mathrm{~K}$ protein at residues 248-250, 418-420, and 477-479, respectively (GenEmbl accession number X04654). This suggests that recognition of the retroviral domain may lead to epitope spreading through binding to RRE triplets within the $70 \mathrm{~K}$ protein. It is well known that highly charged polypeptides can elicit high titre antibodies. ${ }^{55}$ Therefore, the presence of charged amino acids in the mimicking epitopes may have important implications in triggering cross reactive antibodies of high affinity. HRES- 1 is represented as a single copy element per haploid genome that has been mapped to a common fragile site of chromosome 1 at q42..$^{56}$ The presence or absence of a polymorphic HindIII site defines two different allelic forms of the HRES- 1 genomic locus. ${ }^{54}$ In comparison with normal blood donors, a differential segregation of polymorphic genotypes of the HRES-1 locus - that is, a relative decrease of genotype I and increase of genotype III were noted among patients with SLE. ${ }^{57}$ The $\mathrm{q} 41 \rightarrow \mathrm{q} 42$ region of chromosome 1 was found to contain susceptibility genes that confer risk for SLE in multiple ethnic groups, ${ }^{58}$ further supporting the notion that HRES-1 or another gene(s) closely linked to HRES-1 may influence susceptibility to SLE.

A mimicking epitope between another lupus autoantigen, Sm, and HIV-1 p24 gag was defined based on cross reactivity with monoclonal antibody $4 \mathrm{~B} 4 .{ }^{59}$ A proline rich

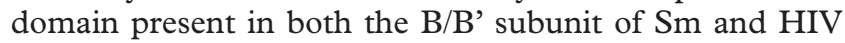
p24 gag was suggested to be the core of cross reactive epitopes. Antibodies binding to HIV-1 p24 gag were found in 22 of 61 patients with SLE. ${ }^{59}$ A region of considerable homology, comprised of 11 highly charged residues (GRGRGRGRGRG), was identified as a site of cross reac- tivity between the $\mathrm{D}$ component of $\mathrm{Sm}$ and the Epstein-Barr virus nuclear antigen 1 (EBNA-1) ${ }^{60}$ Mimicry between EBNA-1 and another self protein, the $71 \mathrm{kDa}$ p542 has been shown in patients with SLE and other autoimmune diseases. ${ }^{61}$ The mimicking epitope, a 28 -mer glycine-rich sequence was selectively recognised by serum samples from autoimmune patients while it was uncommonly targeted by serum samples from normal donors. The concept that EBV can trigger IgG antibodies that cross react with autoantigens is an attractive one. EBV is a ubiquitous human DNA virus that infects $B$ cells and causes their polyclonal activation and thus polyclonal antibody production. Such polyclonal B cell activation may be an early step in pathogenesis of SLE. ${ }^{62}$ Interestingly, prevalence of EBV infection was reported to be as high as $99 \%$ in young SLE patients in comparison with a $70 \%$ prevalence in controls. ${ }^{63}$ Therefore, EBV has the potential to trigger lupus by two mechanisms: polyclonal $\mathrm{B}$ cell activation and molecular mimicry. The ICP4 protein of another ubiquitous human DNA virus, human herpesvirus type I (HHV-1) shows cross reactivity with the C component of U1 snRNP. ${ }^{64}$ A region with limited sequence homology to feline sarcoma virus (FSV) gag protein was noted in the La antigen. ${ }^{65}$ Antibodies to the env protein of an ERS, ERV-3, were reported in patients with SLE with the highest prevalance in mothers of babies with complete heart block (CHB). ${ }^{50}$

ERS, in addition to serving as cross reactive targets of antiviral immunity, may also have a direct role in regulating immune responses. A synthetic heptadecapeptide (CKS17) corresponding to the transmembrane domain of of the env protein conserved among many exogenous and endogenous retroviruses has potent immunosuppressive properties (table 3) ${ }^{66}$ ERS and other retrotransposable elements possess a relatively high mobility and thus represent a major factor in shaping and reorganisation of the eukaryotic genome. ${ }^{67}$ The ERS HERV-K10 was found to have an integration site in the human complement C2 gene. ${ }^{68}$ Variable repeats of this element may have a role in polymorphism and differential expression of C2 loci. Integration of a $5.3 \mathrm{~kb}$ ETn retrotransposon in the FasR gene

Table 3 Viral proteins mimic immunoregulatory abnormalities of rheumatic disease

\begin{tabular}{|c|c|c|}
\hline Virus/viral product & Mechanism/effect & Reference \\
\hline \multicolumn{3}{|c|}{ Change in lymphokine milieu } \\
\hline All viral dsRNA or DNA & induction of IFNs & $(108)$ \\
\hline \multirow[t]{3}{*}{ HTLV-I p40/tax } & increases IL2R expression & $(109)$ \\
\hline & stimulates apoptosis through bcl 2 & $(98)$ \\
\hline & inhibits apoptosis through Fas and oxidative stress & $(99,100)$ \\
\hline HIV-1 gp41 (aa581-597) & inhibits PKC activity and IL2 production & $(75)$ \\
\hline HIV-1 nef & binds lck, inhibits Th1 cytokine production & $(110)$ \\
\hline HIV-1 tat & inhibits Th1 cytokine IL 12 production & (111) \\
\hline CMV US28 & binds $\mathrm{C}-\mathrm{C}$ chemokines & $(76)$ \\
\hline CKS-17 env domain & inhibits Th1 cytokine production & (66) \\
\hline \multicolumn{3}{|l|}{ Altered antigen presentation } \\
\hline EBV/BZLF2 & Inhibits MHC class II binding & $(81)$ \\
\hline Adenovirus/E1A & Inhibits MHC class I expression & $(80)$ \\
\hline Adenovirus/E3 gp19 & Inhibits MHC class I binding to antigen & $(79)$ \\
\hline $\mathrm{HSV} / \mathrm{ICP} 47$ & Inhibits TAP (MHC) function & (78) \\
\hline \multicolumn{3}{|l|}{ Apoptosis pathways } \\
\hline HTLV-I p $40 / \operatorname{tax}$ & stimulation through blocking bcl-2 & $(98)$ \\
\hline HTLV-I p $40 /$ tax & inhibition of Fas and oxidative stress pathways & $(99,100)$ \\
\hline HIV-1 tat & stimulation through Fas and oxidative stress & $(84,86)$ \\
\hline HIV-1 protease & Stimulation by cleavage of bcl- 2 & $(87)$ \\
\hline HIV-1 vpr & Stimulation through mitotic arrest & $(93,94)$ \\
\hline Parvovirus B19 & Stimulation by unknown mechanism & $(88)$ \\
\hline Influenza/NS1 & Stimulation through Fas and bcl- 2 pathways & $(89)$ \\
\hline Adenovirus E1B 19K & Bcl-2 homologue, inhibits apoptosis & (95) \\
\hline EBV BHRF1 & Bcl-2 homologue, inhibits apoptosis & (96) \\
\hline HSV $\gamma_{1} 34.5$ & Inhibition by unknown mechanism & $(97)$ \\
\hline HBV pX & Inhibition, p53 antagonist & (92) \\
\hline EHV-2 23 K E8-vFLIP & Inhibition of Fas pathway & $(104,105)$ \\
\hline MCV ORF159L-vFLIP & Inhibition of Fas pathway & $(104,105)$ \\
\hline HVS ORF71-vFLIP & Inhibition of Fas pathway & $(104,105)$ \\
\hline HHV-8 ORF189-vFLIP & Inhibition of Fas pathway & $(104,105)$ \\
\hline
\end{tabular}


locus resulted in dysruption of this apoptosis pathway in lupus prone $\mathrm{MRL} / \mathrm{lpr}$ mice. ${ }^{69}$

VIRAL PROTEINS MODULATE CYTOKINE PRODUCTION

Functional abnormalities of $\mathrm{T}$ and $\mathrm{B}$ cells have been correlated with an altered cytokine production profile in patients with rheumatic disease. ${ }^{70}$ Secretion of $\mathrm{T}$ helper type 1 (Th1) cytokines, interleukin 2 (IL2), interferon $\gamma$ (IFN $\gamma$ ), and IL12, necessary for maintenance of a classic $\mathrm{T}$ cell mediated immunity, is diminished while production of Th2 cytokines, in particular, IL4, IL5, IL6 and IL10, promoting $\mathrm{B}$ cell function, is increased in patients with SLE. ${ }^{70}$ This marked shift in cytokine production may be related to a fundamental biochemical defect manifested in deficiencies of protein kinase A activity, increased phosphatidylinositol turnover and diminished protein kinase $\mathrm{C}$ activities in lupus $\mathrm{T}$ cells. ${ }^{71}$

Changes in production of cytokines similar to those in patients with SLE, a shift from a Th1 to a Th2 type cytokine profile, have been described as a result of HIV-1 infection. ${ }^{72} \mathrm{CD} 4 \mathrm{~T}$ cell decline is mediated by an increased rate of apoptosis or programmed cell death (PCD). ${ }^{40}$ Interestingly, Th1 type cytokines protect against apoptosis, while Th 2 cytokines increase PCD.$^{72}$ Accelerated apoptosis has also been described in SLE. ${ }^{41}$ Moreover, apoptosis has been associated with a compartmentalised release of autoantigens in patients with SLE. ${ }^{73}$ These observations raise the possibility that increased apoptosis and autoantibody production may be mediated by somewhat similar mechanisms both in AIDS and SLE. The nef, and tat genes of HIV-1 are thought to mediate a Th1 to Th2 shift in cytokine production (table 3 ). A synthetic env heptadecapeptide, CKS-17 down regulates cell mediated immune responses, ${ }^{66}$ possibly via suppression of Th1 type cytokine production. ${ }^{74}$ The CKS-17 motif was found to be highly conserved among infectious and endogenous retroviruses. $^{74}$ Down regulation of IL2 production in HIV infected cells was also linked with inhibition of protein kinase C (PKC) activity and influx of $\mathrm{Ca}^{++} \cdot{ }^{75}$ US28 of HCMV binds members of the $\alpha$ or C-C family of chemokines. ${ }^{76}$ Polymorphisms of chemokine receptors are important factors determining sensitivity to infection by HIV- $1 .{ }^{77}$ Development of CAEV induced arthritis is also associated with a Th1 to Th2 shift in cytokine production. $^{36}$

VIRAL PROTEINS MODULATE ANTIGEN PRESENTATION

MHC haplotypes have been associated with susceptibility to rheumatic diseases and recognition of specific autoantigens. ${ }^{1}$ This is consistent with a dominant role of the MHC in selection and presentation of antigenic peptides. Interestingly, viral peptides influence expression of MHC class I and class II antigens as well as the function of TAP proteins (transporters associated with antigen presentation). Thus, herpes simplex virus (HSV) encodes a cytosolic protein, ICP47, which interferes with the function of the TAP1/TAP2 complex, prevents association of peptide with MHC class I, and leads to degradation of empty class I molecules. ${ }^{78} \mathrm{E} 3$ gp 19 of adenovirus type $2^{79}$ and E1A of adenovirus type 12 also inhibit expression of MHC class I. ${ }^{80}$ E1A was shown to directly interfere with negative regulatory elements in the $\mathrm{MHC}$ class I promoter. ${ }^{80}$ The BZLF2 protein of EBV recognises the peptide binding pocket of the HLA-DR $\beta$ chain and interferes with class II directed antigen presentation. ${ }^{81}$ In addition, expression of MHC proteins is dependent on production of cytokines, such as IFN $\gamma$ and $T N F \alpha$, production of which is often inhibited by viral infections. ${ }^{82} 83$ The above data indicate that viruses commonly infecting the general population, including patients with rheumatic diseases, affect antigen presentation and modulate the cytokine milieu, which may in turn play a part in initiation or perpetuation of autoimmunity.

\section{REGULATION OF APOPTOSIS BY VIRAL PROTEINS}

Apoptosis or programmed cell death (PCD) represents a physiological mechanism for elimination of autoreactive lymphocytes during development. Viral infections may have a role in dysregulation of apoptosis in autoimmune patients. Many viruses have evolved genes that can selectively inhibit or stimulate PCD. The suicide of an infected cell by internal activation of apoptosis or the killing of an infected cell by a cytotoxic T lymphocyte or NK cell may be viewed as a defence mechanism of the host to prevent viral propagation. In the early stages of infection, viral inhibitors of apoptosis allow for more extensive production of progeny. At later stages, viral inducers of apoptosis facilitate spread of progeny to uninfected cells.

HIV may use several mechanism to deplete CD4+ T cells at the later stages of disease (table 3 ). The tat protein induces oxidative stress, ${ }^{84} 85$ and increases surface expression of the Fas ligand resulting in accelerated signaling through the Fas pathway. ${ }^{84}{ }^{86}$ In addition, cleavage of bcl-2 by HIV protease may expose the cell to a variety of apoptotic signals. ${ }^{87}$ Parvovirus B19 depletes erythroid progenitor cells by apoptosis. ${ }^{88}$ Cells infected by influenza virus undergo PCD that can be inhibited by bcl-2 and facilitated through the Fas pathway. ${ }^{89}$ It is intriguing to consider the possiblity that viruses causing common cold may stimulate antinuclear autoantibody production through periodic release of nucleosomes from apoptotic cells. Thus, chronic parvovirus B19 infection was recently associated with production of a wide array of autoantibodies..$^{90}$ Replication of CAEV is also associated with induction of apoptosis. ${ }^{91}$

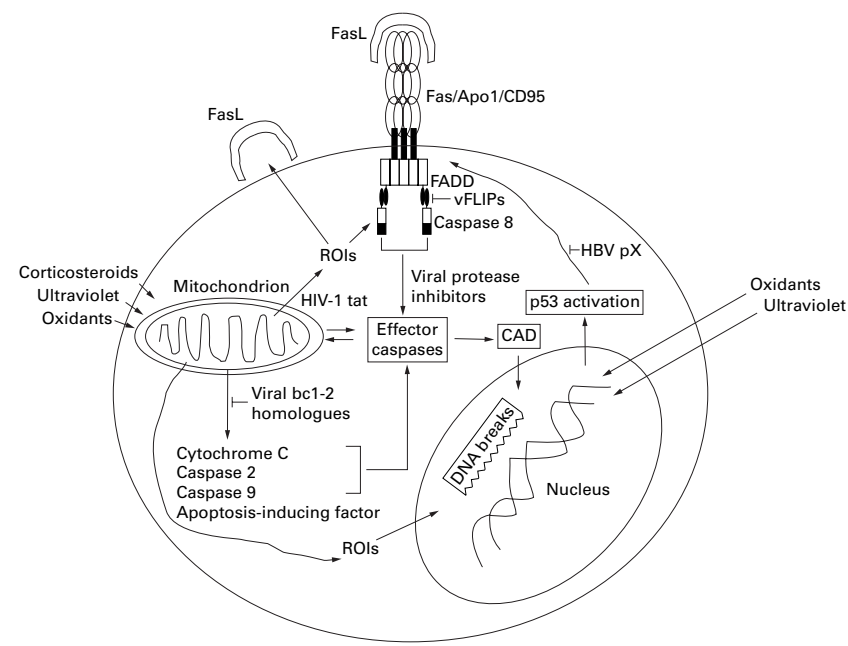

Figure 1 Regulation of apoptosis pathways by viral proteins. Oxidants, ultra violet light, and corticosteroids trigger apoptosis by mitochondrial damage, which, in turn, leads to the release of caspase activating factors. ${ }^{112}$ This process is inhibited by bcl-2 and its viral homologues. Release of reactive oxygen intermediates causes increased production of FasL and DNA fragmentation. Fas ligand (FasL) crosslinks the Fas receptor (Fas/Apo1/CD95), which recruits an adapter protein with a Fas associated death domain (FADD). Viral FLIPs (vFLIPS) possess a death effector domain similar to those of FADD and caspase 8 and, thus, interrupt Fas signalling. While not shown, vFLIPs may also block TNF receptor mediated signalling through FADD shared by both the Fas and TNF pathways. ${ }^{113}$ Upon recruitment of caspase 8 , its oligomerisation causes self cleavage and activation of downstream effector caspases. ${ }^{113} \mathrm{~A}$ caspase activated DN-ase cleaves chromosomal DNA. Oxidants and ultra violet light as well as ROI released from damaged mitochondria cause DNA fragmentation, which in turn activates p53. p53 induces oxidative stress and augments surface expression of the Fas receptor. HIV-1 tat increases mitochondrial ROI production thus increasing apoptosis. By contrast $H B V p X$ protein interferes with the proapoptotic effects of $p 53$. 
Inhibition of apoptosis by viral proteins help infected cells to evade inflammatory responses, such as killing by cytotoxic $\mathrm{T}$ cells through the Fas and TNF pathways (fig 1). $\mathrm{pX}$ protein of hepatitis $\mathrm{B}$ virus (HBV) inhibits binding of p53 to DNA. ${ }^{92}$ The vpr gene of HIV-1 causes cells to arrest in the G2 phase of the cell cycle when virus expression is highest. ${ }^{93}{ }^{94}$ Viral homologues of bcl-2 can functionally subsitute for bcl-2 in binding to the apoptosis accelerating proteins, bax, bad, and bag. ${ }^{95}{ }^{96}$ Persistence of herpes simplex virus (HSV) in neurons has been linked to its apoptosis inhibitory protein $\gamma_{1} 34.5 .{ }^{97}$ The $\mathrm{p} 40 /$ tax protein of HTLV-I seems to possess both apoptosis inducing ${ }^{98}$ and inhibiting capabilities. ${ }^{99}{ }^{100} \mathrm{Up}$ regulation of thioredoxin, a NADPH dependent antioxidant ${ }^{99}$ and inhibition of Fas dependent signalling have been implicated in the antiapoptotic effect of HTLV-I tax protein. ${ }^{100}$ These two mechanisms are not mutually exclusive as Fas induced cell death is accompanied by the formation of reactive oxygen intermediates (ROI) and is subject to regulation by enzymes of the pentose phosphate pathway providing $\mathrm{NADPH}$ as a source of reducing equivalent for intracellular antioxidants. ${ }^{101}$ p40/tax may mediate autoimmune arthropathy ${ }^{102}$ and Sjögren's syndrome by blocking Fas dependent cell death in HTLV-I/tax transgenic mice. ${ }^{103} \mathrm{~A}$ new family of viral inhibitors, designated as vFLIPs (viral FLICE inhibitory proteins), has recently been discovered. ${ }^{104105}$ vFLIPs are produced by several $\gamma$-herpesviruses, including the Kaposi-sarcoma associated human herpesvirus 8 (HHV-8), the tumorigenic human molluscipoxvirus (MCV), herpesvirus saimiri (HVS), and equine herpesvirus 2 (EHV-2). vFLIPs block the early signalling events triggered through the death receptors Fas, TRAMP, TRAIL-R and TNFR1. Thus, herpesviruses evolved a series of genes that allow selective blocking of the Fas and TNF signalling pathways.

\section{Conclusion and future directions}

The experimental evidence presented above shows immunological cross reactivities between autoantigens and viruses. The concept that autoimmunity is triggered in genetically susceptible hosts by trivial environmental factors, possibly different from patient to patient, is consistent with the general epidemiology - that is, a relatively sporadic occurrence, of the disease. ${ }^{106}$ Moreover, proteins of commonly occurring viruses have profound effects on the cytokine milieu, antigen recognition, and lymphocyte cell survival. Thus, molecular mimicry and immunomodulation by viral proteins may account for both cross reactivity with autoantigens and abnormal $\mathrm{T}$ and $\mathrm{B}$ cell funtions in autoimmune disorders. Causal association of HCV with type II cryoglobulinaemias and of HTLV-I with polymyositis, Sjögren's syndrome, and erosive arthritis represent significant discoveries for rheumatology. Patients infected with HCV or HTLV-I invariably have high titre antiviral antibodies. Likewise, serum samples of autoimmune patients are likely to contain antibodies specific for viruses of pathogenetic significance. Thus, autoimmune serum samples could be used as tools for isolating viral nucleic acids by careful screening of expression libraries of differencial display. ${ }^{107}$ Alternatively, further studies on previously characterised infectious and endogenous viral elements are needed. Continued research on viral pathogenesis is likely to provide future breakthroughs for the diagnosis and treatment of rheumatic diseases.

We thank Dr Katalin Banki for critical review of the manuscript and Dr Paul Phillips for continued encouragement and support.
Funding: this work was supported in part by grant RO1 DK 49221 from the National Institutes of Health, grant RG 2466A1/3 from the National Multiple Sclerosis Society, the Arthritis Foundation, and the Central New York Community Foundation.

ANDRAS PERL

Departments of Medicine and Microbiology and Immunology, State University of New York Health Science Center, College of Medicine, 750 East Adams Street, Syracuse, NY 13210, USA

1 Arnett FC, Reveille JD. Genetics of systemic lupus erythematosus. Rheum Dis Clin North Am 1992;18:865-92.

2 Rothschild BM, Woods RJ, Rothschild C, Sebes JI. Geographic distribution of rheumatoid arthritis in ancient North America: Implications for pathoof rheumatoid arthritis in ancient North Americ:

3 Naides SJ. Rheumatic manifestations of parvovirus B19 infection. Rheum Dis Clin North Am 1998;24:375-401.

4 Phillips PE. Viral arthritis. Curr Opin Rheumatol 1997;9:337-44.

Tingle AJ, Mitchell LA, Grace M, Middleton P, Mathias R, MacWilliam L. Randomised double-blind placebo-controlled study on adverse effects of rubella immunisation in seronegative women. Lancet 1997;349:1277-81.

6 Ray P, Black S, Shinefield H, Dillon A, Schwalbe J, Holmes S, et al. Risk of chronic arthropathy among women after rubella vaccination. Vaccine Safety Datalink Team [see comments]. JAMA 1997;278:551-6.

7 Frenkel LM, Nielsen K, Garakian A, Jin R, Wolinsky JS, Cherry JD. A search for persistent rubella virus infection in persons with chronic symptoms after rubella and rubella immunization and in patients with juvenile rheumatoid arthritis. Clin Infect Dis 1996; 22:287-94.

8 Flexman JP, Smith DW, Mackenzie JS, Fraser JR, Bass SP, Hueston L, et al. A comparison of the diseases caused by Ross River virus and Barmah ForA comparison of the diseases caused by

9 Fraser JR, Becker GJ. Mononuclear cell types in chronic synovial effusions of Ross River virus disease. Aust N Z J Med 1984;14:505-6.

10 Fraser JR, Ratnamohan VM, Dowling JP, Becker GJ, Varigos GA. The exanthem of Ross River virus infection: histology location of virus antigen and nature of inflammatory infiltrate. J Clin Pathol 1983;36:1256-63.

11 Fraser JR. Epidemic polyarthritis and Ross River virus disease. Clin Rheum Dis 1986;12:369-88.

12 Panush RS. Adenovirus arthritis. Arthritis Rheum 1974;17:534-6.

13 Rahal JJ, Millian SJ, Noriega ER. Coxsackie and adenovirus infection. Association with acute febrile and juvenile rheumatoid arthritis. JAMA 1976;235:2496-501.

14 Fraser KJ, Clarris BJ, Muirden KD, Fraser JR, Jack I. A persistent adenovirus type 1 infection in synovial tissue from an immunodeficient patient with chronic, rheumatoid-like polyarthritis. Arthritis Rheum 1985;28:455-8.

15 Modlin JF. Coxsackieviruses, echoviruses, and newer enteroviruses. Mandell GL, Bennett JE, Dolin R, eds. Principles and practice of infectious diseases. GL, Bennett JE, Dolin R, eds. Principles and

16 Ray CG, Gall EP, Minnich LL, Roediger J, De Benedetti C, Corrigan JJ. Acute polyarthritis associated with active Epstein-Barr virus infection. JAMA 1982;248:2990-3

17 Le Goff P, Chicault P, Saraux A, Baron D, Valls-Bellec I, Leroy JP. Lymphoma with regression after methotrexate withdrawal in a patient with rheumatoid arthritis. Role for the Epstein-Barr virus. Rev Rheum Engl Ed 1998;65:283-6.

18 Natkunam Y, Elenitoba-Johnson KS, Kingma DW, Kamel OW. EpsteinBarr virus strain type and latent membrane protein 1 gene deletions in lymphomas in patients with rheumatic diseases. Arthritis Rheum 1997;40: 1152-6.

19 Stebbings S, Highton J, Croxson MC, Powell K, McKay J, Rietveld J. Chickenpox monoarthritis: demonstration of varicella-zoster virus in joint fluid by polymerase chain reaction. Br J Rheumatol 1998;37:311-13.

20 Naucler CS, Larsson S, Moller E. A novel mechanism for virus-induced autoimmunity in humans. Immunol Rev 1996;152:175-92.

21 Ferri C, La Civita L, Longombardo G, Zignego AL, Pasero G. Mixed cryoglobulinaemia: a cross-road between autoimmune and lymphoproliferative disorders. Lupus 1998;7:275-9.

22 Akriviadis EA, Xanthakis I, Navrozidou C, Papadopoulos A. Prevalence of cryoglobulinemia in chronic hepatitis $\mathrm{C}$ virus infection and response to treatment with interferon-alpha. J Clin Gastroenterol 1997;25:612-18.

23 Ferri C, Greco F, Longombardo G, Palla P, Moretti A, Marzo E, et al. Association between hepatitis $C$ virus and mixed cryoglobulinemia. Clin Exp Rheumatol 1991;9:621-4

24 Gorevic PD, Kassab HJ, Levo Y, Kohn R, Meltzer M, Prose P, et al. Mixed cryoglobulinemia: clinical aspects and long-term follow-up of 40 patients. Am J Med 1980;69:287-308.

25 Perl A, Gorevic PD, Ryan DH, Condemi JJ, Ruszkowski RJ, Abraham GN. Clonal B cell expansions in patients with essential mixed cryoglobulinaemia. Clin Exp Immunol 1989;76:54-60.

26 Ferri C, Monti M, La Civita L, Longombardo G, Greco F, Pasero G, et al. Infection of peripheral blood mononuclear cells by hepatitis $\mathrm{C}$ virus in mixed cryoglobulinemia. Blood 1993;82:3701-4

27 Jackson JM, Callen JP. Scarring alopecia and sclerodermatous changes of the scalp in a patient with hepatitis C infection. J Am Acad Dermatol 1998; 39:824-6

28 Nishioka K. HTLV-I arthropathy and Sjogren syndrome. J Acquir Immune Defic Syndr Hum Retrovirol 1996;13 (suppl 1):S57-62.

29 Guerin B, Arfi S, Numeric P, Jean-Baptiste G, Le Parc JM, Smadja D. Polyarthritis in HTLV-1-infected patients. A review of 17 cases. Rev Rhum Engl Ed 1995;62:21-8.

30 Beilke MA, Traina-Dorge V, England JD, Blanchard JL. Polymyositis, arthritis, and uveitis in a macaque experimentally infected with human $\mathrm{T}$ lymphotropic virus type I. Arthritis Rheum 1996;39:610-15.

31 Weitzul S, Duvic M. HIV-related psoriasis and Reiter's syndrome. Seminars in Cutaneous Medicine and Surgery 1997;16:213-18.

32 Espinoza LR, Cuellar ML. Retrovirus-associated rheumatic syndromes. Koopman WJ, ed. Arthritis and allied conditions. Baltimore: Williams and Koopman WJ, ed. Arth

33 Sigurdsson B, Palsson P, Grimsson H. Visna, a demyelinating transmissible disease of the sheep. J Neuropathol Exp Neurol 1957;16:389-403. 
34 Narayan O, Cork LC. Lentiviral diseases of sheep and goats: chronic pneumonia leukoencephalomyelitis and arthritis. Reviews of Infectious Diseases $1985 ; 7: 89-98$.

35 Cork LC, Hadlow WJ, Crawford TB, Gorham JR, Piper RC. Infectious leukoencephalomyelitis of young goats. J Infect Dis 1974;129:134-41.

36 Cheevers WP, Beyer JC, Knowles DP. Type 1 and type 2 cytokine gene caprine arthritis-encephalitis lentivirus infection. J Virol 1997;71:625963.

37 Lechner F, Vogt HR, Seow HF, Bertoni G, Cheevers WP, von Bodungen U, et al. Expression of cytokine mRNA in lentivirus-induced arthritis. Am J Pathol 1997;151:1053-65.

38 Rich SA Human lupus inclusions and interferon. Science 1981 213:772-5.

39 Stransky G, Vernon J, Aicher WK, Moreland LW, Gay RE. Virus-like particles in synovial fluids from patients with rheumatoid arthritis. $\mathrm{Br} \mathrm{J}$ Rheumatol 1993;32:1044-8.

40 Meyaard L, Otto SA, Jonker RR, Mijnster MJ, Keet RPM, Miedema F. Programmed death of T cells in HIV infection. Science 1992;257:217-19.

41 Emlen W, Niebur JA, Kadera R. Accelerated in vitro apoptosis of lymphocytes from patients with systemic lupus erythematosus. J Immunol 1994;152:3685-92.

42 Calabrese L. The rheumatic manifestations of infection with the HIV. Semin Arthritis Rheum 1989;18:225-39.

43 Inman RD, Perl A, Phillips PE. Infectious agents in chronic rheumatic diseases. Koopman WJ, ed. Arthritis and allied conditions. A textbook of rheumatology. Philadelphia: Lea and Febiger, 1997:585.

44 Yoshiki T, Mellors RC, Strand M, August JT. The viral envelope glycoprotein of murine leukemia virus and the pathoegenesis of immune complex tein of murine leukemia virus and the pathoegenesis of immune complex
glomerulonephritis of New Zealand mice. J Exp Med 1974;140:1011-25.

45 Krieg AM, Gourley MF, Perl A. Endogenous retroviruses: potential etiologic agents in autoimmunity. FASEB J 1992;6:2537-44.

46 Banki K, Maceda J, Hurley E, Ablonczy E, Mattson DH, Szegedy L, et al. Human T-cell lymphotropic virus (HTLV)-related endogenous sequence,
HRES-1, encodes a 28-kDa protein: a possible autoantigen for HTLV-I gag-reactive autoantibodies. Proc Natl Acad Sci USA 1992;89:1939-43.

47 Perl A, Colombo E, Dai H, Agarwal RK, Mark KA, Banki K, et al. Antibody reactivity to the HRES-1 endogenous retroviral element identifies a subset of patients with systemic lupus erythematosus and overlap syndromes: correlation with antinuclear antibodies and HLA class II alleles. Arthritis Rheum 1995;38:1660-71.

48 Brookes SM, Pandolfino YA, Mitchell TJ, Venables TJW, Shattles WG, Clark DA, et al. The immune response to and expression of cross-reactive Clark DA, et al. The immune response to and expression of cross-reactive
retroviral gag sequences in autoimmune disease. Br J Rheumatol 1992;31: 735-42.

49 Bengtsson A, Blomberg J, Nived O, Pipkorn R, Toth L, Sturfelt G. Selective antibody reactivity with peptides from human endogenous retroviruses and nonviral poly(amino acids) in patients with systemic lupus erythematosus. Arthritis Rheum 1996;39:1654-63.

$50 \mathrm{Li}$ J, Fan WS, Horsfall AC, Anderson AC, Rigby S, Larsson E, et al. The expression of human endogenous retrovirus- 3 in fetal cardiac tissue and antibodies in congenital heart block. Clin Exp Immunol 1996;104:388-93. Oldstone MBA.

52 Albani S, Carson DA. A multistep molecular mimicry hypothesis for the pathogenesis of rheumatoid arthritis. Immunol Today 1996;17:466-70.

53 Query CC, Keene JD. A human autoimmune protein associated with U1 RNA contains a region of homology that is cross-reactive with retroviral p30 contains a region of homology

54 Perl A, Rosenblatt JD, Chen IS, DiVincenzo JP, Bever R, Poiesz BJ, et al. Detection and cloning of new HTLV-related endogenous sequences in man. Nucleic Acids Res 1989;17:6841-54.

55 Sela M. Antigenicity: some molecular aspects. Science 1969;166:1365-74. Perl A, Isaacs CM, Eddy RL, Byers MG, Sait SN, Shows TB. The human
T-cell leukemia virus-related endogenous sequence (HRES1) is located on T-cell leukemia virus-related endogenous sequence
chromosome 1 at q42. Genomics 1991;11:1172-3.

57 Magistrelli C, Banki K, Ferrante P, Perl A. Mapping and cloning of polymorphic genotypes of the HRES-1 LTR. Arthritis Rheum 1994;37: S316.

58 Tsao BP, Cantor RM, Kalunian KC, Chen C, Badsha H, Singh R, et al. Evidence for linkage of a candidate chromosome 1 region to human systemic lupus erythematosus. J Clin Invest 1997;99:725-31.

59 Talal N, Garry RF, Schur PH, Alexander S, Dauphinee MJ, Livas IH, et al. A conserved idiotype and antibodies to retroviral proteins in systemic lupus erythematosus. J Clin Invest 1990;85:1866-71.

60 Sabbatini A, Bombardieri S, Migliorini P. Autoantibodies form patients with systemic lupus erythematosus bind a shared sequence of $\mathrm{SmD}$ and Epstein-Barr virus-encoded nuclear antigen EBNA I. Eur J Immunol 1993;23:1146-52.

61 Vaughan JH, Nguyen M, Valbracht JR, Patrick K, Rhodes GH. Epstein-Barr Virus-induced Autoimmune Responses II. Immunoglobulin G autoantibodies to mimicking and nonmimicking epitopes. Presence in autoimmune disease. J Clin Invest 1995;95:1316-27.

62 Steinberg AD, Gourley MF, Klinman DM, Tsokos GC, Scott DE, Krieg AM. Systemic lupus erythematosus. Ann Intern Med 1991;115:548-59.

63 James JJ, Kaufman KM, Farris AD, Taylor-Albert E, Lehman TJA, Harley JB. An increased prevalence of Epstein-Barr virus infection in young patientts suggests a possible etiology for systemic lupus erythematosus. J Clin Invest 1997;100:3019-26.

64 Misaki Y, Yamamoto K, Yanagi K, Miura H, Ichijo H, Kato T, et al. B cell epitope on the U1 snRNP-C autoantigen contains a sequence similar to that of the herpes simplex virus protein. Eur J Immunol 1993;23:1064-71.

65 Kohsaka H, Yamamoto K, Fujii H, Miura H, Miyasaka N, Nishioka K, et al. Fine epitope mapping of the human SS-B/La protein. Identification of a distinct autoepitope

66 Cianciolo GJ, Copeland TD, Oroszlan S, Snyderman R. Inhibition of lymphocyte proliferation by a synthetic peptide homologous to retroviral envelope proteins. Science 1985;230:453-5.

67 Perl A, Banki K. Human endogenous retroviral elements and autoimmunity: data and concepts. Trends Microbiol 1993;1:153-6.

$68 \mathrm{Zhu}$ ZB, Hsieh S, Bentley DR, Campbell D, Volanakis JE. A variable number of tandem repeat locus within the human complement $\mathrm{C} 2$ gene is J Exp Med 1992;175:1783-87.
69 Nagata S, Golstein P. The Fas death factor. Science 1995;267:1449-56.

70 Tsokos GC. Overview of cellular immune function in systemic lupu erythematosus. Lahita RG, ed. Systemic lupus erythematosus. New York: Churchill Livingstone, 1992:15.

71 Dayal AK, Kammer GM: The T cell enigma in lupus. Arthritis Rheum 1996;39:23-33.

72 Clerici M, Shearer GM. The Th1-Th2 hypothesis of HIV infection: new insights. Immunol Today 1994;15:575-81.

73 Casciola-Rosen LA, Anhalt G, Rosen A. Autoantigens targeted in systemic lupus erythematosus are clustered in two populations of surface structures on apoptotic keratinocytes. J Exp Med 1994;179:1317-30.

74 Haraguchi S, Good RA, Day NK. Immunosuppressive retroviral peptides: cAMP and cytokine patterns. Immunol Today 1995;16:595-603.

75 Ruegg CL, Strand M. A synthetic peptide with sequence identity to the transmembrane protein gp41 of HIV-1 inhibits distinct lymphocyte activation pathways dependent on protein kinase $\mathrm{C}$ and intracellular calcium influx. Cell Immunol 1991;137:1-13.

76 Gao J, Murphy PM. Human cytomegalovirus open reading frame US28 encodes a functional $\beta$ chemokine receptor. J Biol Chem 1994;269:2853942.

77 Paxton WA, Dragic T, Koup RA, Moore JP. The $\beta$-chemokines, HIV type 1 second receptors, and exposed uninfected persons. AIDS Res Hum Retroviruses 1996;12:1203-7.

78 Hill A, Jugovic P, York I, Russ G, Bennink J, Yewdell J, et al. Herpes simplex virus turns off the TAP to evade host immunity. Nature 1995;375:411-15.

79 Burgert $\mathrm{H}$, Kvist $\mathrm{S}$. The E3/19K protein of adenovirus type 2 binds to the domains of histocompatibility antigens required for CTL recognition. EMBO J 1987;6:2019-26.

80 Proffitt JL, Sharma E, Blair GE. Adenovirus 12-mediated down-regulation of the major histocompatibility complex (MHC) class I promoter: identification of a negative regulatory element responsive to Ad12 E1A. Nucleic Acids Res 19

81 Li Z, Turk SM, Hutt-Fletcher LM. The Epstein-Barr virus (EBV) BZLF2 gene product associates with the gH and gL homologs of EBV and carries an epitope critical

82 Mossman K, Upton C, McFadden G. The myxoma virus-soluble interferon-gamma receptor homolog, $\mathrm{M}-\mathrm{T} 7$, inhibits interferon -gamma in a species-specific manner. J Biol Chem 1995;270:3031-8.

83 Upton C, Macen JL, Schreiber M, McFadden G. Myxoma virus expresses a secreted protein with homology to the tumor necrosis factor receptor gene family that contributes to viral virulence. Virology 1991;184:370-82.

84 Ehret A, Westendorp MO, Herr I, Debatin K, Heeney JL, Frank R, et al. Resistance of chimpanzee $T$ cells to human immunodeficiency virus type $I$ tat-enhanced oxidative stress and apoptosis. J Virol 1996;70:6502-7.

85 Banki K, Hutter E, Gonchoroff NJ, Perl A. Molecular ordering in HIV-induced apoptosis: Oxidative stress, activation of caspases, and cell survival are regulated by transaldolase. J Biol Chem 1998;273:1 1944-53.

86 Westendorp MO, Frank R, Ochsenbauer C, Stricker K, Dhein J, Walczak H et al. Sensitization of T cells to CD95-mediated apoptosis by HIV-1 tat and gp120. Nature 1995;375:497-500.

87 Strack PR, Frey MW, Rizzo CJ, Cordova B, George HJ, Meade R, et al. Apoptosis mediated by HIV protease is preceeded by cleavage of bcl-2. Proc Natl Acad Sci USA 1996;93:9571-6.

88 Morey AL, Ferguson DJ, Fleming KA. Ultrastructural features of fetal erythroid precursors infected with parvovirus B19 in vitro: evidence for cell death by apoptosis. J Pathol 1993;169:213-20.

89 Hinshaw VS, Olsen CW, Dybdahl-Sissoko N, Evans D. Apoptosis: mechanism of cell killing by influenza $A$ and $B$ viruses. J Virol 1994;68:3667-73

90 Lunardi C, Tiso M, Borgato L, Nanni L, Millo R, De Sandre G, et al. Chronic parvovirus B19 infection induces the production of anti-virus antibodies with autoantigen binding properties. Eur J Immunol 1998;28: 936-48

91 Gendelman R, Orzech Y, Mashiah P, Birenbaum M, Gazit A, Yaniv A. Productive replication of caprine arthritis-encephalitis virus is associated with induction of apoptosis. J Gen Virol 1997;78:801-5.

92 Wang XW, Gibson MK, Vermeulen W, Yeh H, Forrester K, Sturzbecher HW, et al. Abrogation of $\mathrm{p} 53$-induced apoptosis by the hepatitis B virus $\mathrm{X}$ . Cancer Res 1995;55:6012-16.

93 Bartz SR, Rogel ME, Emerman M. Human immunodeficiency virus type 1 cell cycle control: $\mathrm{Vpr}$ is cytostatic and mediates $\mathrm{G}_{2}$ accumulation by a mechanism which differs from DNA damage checkpoint control. J Virol 1996:70:2324-31.

94 Planelles V, Jowett JBM, Li Q, Xie Y, Hahn B, Chen ISY. Vpr-induced cell cycle arrest is conserved among primate lentiviruses. J Virol 1996;70:251624.

95 Rao L, Debbas M, Sabbatini P, Hockenberry D, Korsmeyer S, White E. The adenovirus E1A proteins induce apoptosis which is inhibited by the E1B $19 \mathrm{~K}$ and bcl-2 proteins. Proc Natl Acad Sci USA 1992;89:7742-6.

96 Henderson S, Huen D, Rowe M, Dawson C, Johnson G, Rickinson A. Epstein-Barr virus-coded BHRF1 protein, a viral homologue of bcl-2, protects human B cells fr

97 Chou J, Roizman B. The gamma, 34.5 gene of herpes simplex virus 1 precludes neuroblastoma cells from triggering total shutoff of protein synprecludes neuroblastoma cells from triggering total shutoff of protein synAcad Sci USA 1992;89:3266-70.

98 Yamada T, Yamaoka S, Goto T, Nakai M, Tsujimoto Y, Hatanaka M. The human T-cell leukemia virus type I tax protein induces apoptosis which is blocked by the bcl-2 protein. J Virol 1994;68:3374-9.

99 Masutani H, Hirota K, Sasada T, Ueda-Taniguchi Y, Taniguchi Y, Sono H, et al. Transactivation of an inducible anti-oxidative stress protein, human thioredoxin by HTLV-I tax. Immunol Lett 1996;54:67-71.

100 Kishi S, Saijyo S, Arai M, Karasawa S, Ueda S, Kannagi M, et al. Resistance to Fas-mediated apoptosis of peripheral $\mathrm{T}$ cells in human $\mathrm{T}$ lymphocyte virus type I (HTLV-I) transgenic mice with autoimmune arthropathy. J Exp Med 1997;186:57-64.

101 Banki K, Hutter E, Colombo E, Gonchoroff NJ, Perl A. Glutathione levels and sensitivity to apoptosis are regulated by changes in transaldolase and sensitivity to apoptosis are regulated by

102 Iwakura $Y$, Tosu M, Yoshida E, Takiguchi M, Sato K, Kitajima I, et al. Induction of inflammatory arthropathy resembling rheumatoid arthritis in mice transgenic for HTLV-I. Science 1991;253:1026-28. 
103 Green JE, Hinrichs SH, Vogel J, Jay G. Exocrinopathy resembling Sjogren's syndrome in HTLV-I tax transgenic mice. Nature 1989;341:72-4.

104 Thome M, Schneider P, Hofman K, Fickenscher H, Meinl E, Neipel F, et al. Viral FLICE-inhibitory proteins (FLIPs) prevent apoptosis induced by death receptors. Nature 1997;386:517-21.

105 Bertin J. Death effector domain-containing herpesvirus and poxvirus proteins inhibit Fas- and TNFR1-induced apoptosis. Proc Natl Acad Sci USA 1997;94:1172-6.

106 Hochberg MC. Systemic lupus erythematosus. Rheum Dis Clin North Am 1990;16:617-39.

107 Lisitsyn N, Wigler M. Cloning the differences between two complex genomes. Science 1993;259:946-51.

108 Joklik WK. Interferons. Fields BN, ed. Virology. New York: Raven Press, 1985:281.
109 Cross CL, Feinberg MB, Wolf JB, Holbrook NJ, Wong-Staal F, Leonard WJ. Regulation of the human interleukin-2 receptor alpha promoter: activation of a nonfunctional promoter by the transactivator gene of HTLV-I. Cell 1987;49:47-56.

110 Collette Y, Chang H, Cerdan C, Chambost H, Algarte M, Mawas C, et al. Specific Th1 cytokine down-regulation associated with primary clinically derived human immunodeficiency virus type 1 nef gene-induced expression. J Immunol 1996;156:360-70.

111 Rubartelli A, Poggi A, Sitia R, Zocchi MR. HIV-1 tat: a polypeptide for all seasons. Immunol Today 1998;19:543-5.

112 Green DR, Reed JC. Mitochondria and apoptosis. Science 1998;281: 1309-12.

113 Salvesen GS, Dixit VM. Caspases: intracellular signaling by proteolysis. Cell 1997;91:443-6. 